Article

\title{
High-Precision Land-Cover-Land-Use GIS Mapping and Land Availability and Suitability Analysis for Grass Biomass Production in the Aroostook River Valley, Maine, USA
}

\author{
Chunzeng Wang ${ }^{1, *}$, Jason Johnston ${ }^{1}$, David Vail ${ }^{2}$, Jared Dickinson ${ }^{1}$ and David Putnam ${ }^{1}$ \\ 1 College of Arts and Sciences, University of Maine at Presque Isle, Presque Isle, ME 04769, USA; \\ E-Mails: Jason.johnston@umpi.edu (J.J.); jared_dickinson@umit.maine.edu (J.D.); \\ david.putnam@umpi.edu (D.P.) \\ 2 Bowdoin College, Brunswick, ME 04011, USA; E-Mail: dvail@bowdoin.edu \\ * Author to whom correspondence should be addressed; E-Mail: chunzeng.wang@umpi.edu; \\ Tel.: +1-207-768-9412; Fax: +1-207-768-9553.
}

Academic Editors: Michael Gregory Lloyd and Jane Southworth

Received: 28 September 2014 / Accepted: 16 March 2015 / Published: 20 March 2015

\begin{abstract}
High-precision land-cover-land-use GIS mapping was performed in four major townships in Maine's Aroostook River Valley, using on-screen digitization and direct interpretation of very high spatial resolution satellite multispectral imagery $(15-60 \mathrm{~cm})$ and high spatial resolution LiDAR data $(2 \mathrm{~m})$ and the field mapping method. The project not only provides the first-ever high-precision land-use maps for northern Maine, but it also yields accurate hectarage estimates of different land-use types, in particular grassland, defined as fallow land, pasture, and hay field. This enables analysis of potential land availability and suitability for grass biomass production and other sustainable land uses. The results show that the total area of fallow land in the four towns is 7594 hectares, which accounts for $25 \%$ of total open land, and that fallow plots equal to or over four hectares in size total 4870 , or $16 \%$ of open land. Union overlay analysis, using the Natural Resources Conservation Service (NRCS) soil data, indicates that only a very small percentage of grassland $(4.9 \%)$ is on "poorly-drained" or "very-poorly-drained" soils, and that most grassland (85\%) falls into the "farmland of state importance" or "prime farmland" categories, as determined by NRCS. It is concluded that Maine's Aroostook River Valley has an ample base of suitable, underutilized land for producing grass biomass.
\end{abstract}


Keywords: LCLU mapping; GIS; multispectral imagery; land availability analysis; land suitability analysis; grass biomass; Aroostook; Maine

\section{Introduction}

The Aroostook River Valley in Maine, the United States, spans central Aroostook County and is the most populated and agricultural region in northern Maine, with four principal cities and towns: Presque Isle, Caribou, Fort Fairfield, and Easton (Figure 1). The region's primary economy is largely based on forestry and agriculture. The region has been forested since the end of the last Ice Age and was inhabited by Native Americans until its lumber attracted European settlers during the 18th century. With more settlements in the early 19th century, farming became more important in the region-it was initially dominated by small-grain crops such as oats and wheat and then by potatoes. The settlers found that, unlike the marginal soils covering most of New England, the geologically distinct (the area is mostly underlain by limestone), well-drained, fertile loam soils, along with the cool northern climate and abundant annual precipitation, were perfect for growing potatoes on a large scale. Over the next 100 years, farmers made steady and massive efforts to clear the trees from hundreds of thousands of hectares in order to grow potatoes and other rotational crops. The decade of the 1870 s was a major turning point in the agriculture of Aroostook River Valley, when the arrival of rail tracks stimulated Aroostook's development into a "Potato Empire" [1].

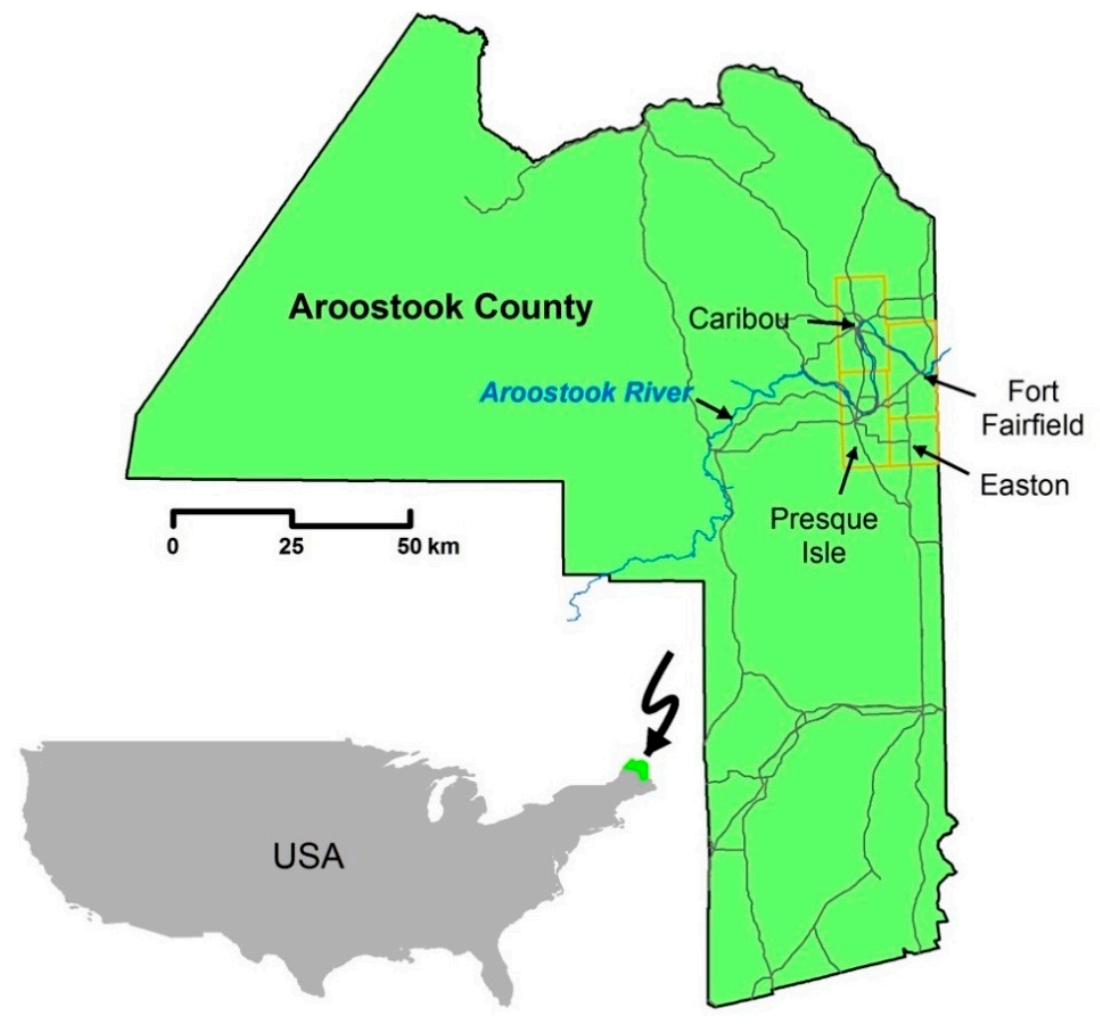

Figure 1. Map showing location of the study area-the four townships of Presque Isle, Caribou, Fort Fairfield, and Easton in the Aroostook River Valley of Aroostook County of northern Maine, USA. 
Aroostook, however, has experienced a considerable decline in actively farmed hectarage since its peak in the 1940s [2]. For example, based on the 2012 United States Department of Agriculture Census of Agriculture results [3], Aroostook County (with most of its farmland located in the central Aroostook River Valley) had 895 farms (with an average size of 157 hectares) compared to 1246 farms in 2007 (a negative change of 28\%) and 142,009 hectares of land in farms compared to 151,987 hectares in 2007 (a negative change of $7 \%$ ); the top crop items in terms of hectarage were potatoes $(25,794$, also including some broccoli), oats for grain $(11,452)$, forage-land used for hay and haylage, grass silage and greenchop (11,073), and barley for grain (6109).

The essential issue is that, although some of the former agricultural land was converted to tree farms or other uses, a considerable amount of land has been abandoned due to publicly supported soil conservation measures, changing market demand for farm commodities, and transfer of ownership to non-farmers. Much of this abandoned land remains idle, either in some stage of woody species succession or bush-hogged annually to maintain future land use potential. Many see this idle land as an opportunity for current or future economic exploitation, either through grass biomass production [4] or renewed cultivation of food and feed crops. For example, abundance of affordable land has recently become attractive to Amish settlers. Since 2007, an Amish community has emerged in central Aroostook, particularly in the towns of Easton and Fort Fairfield. They have converted fallow lands into pastures, hayfields, and even some fodder crop land, bringing dairy farming back to the region and increasing the value of the land. It is anticipated that Amish will continue moving to the area, purchasing more land, especially fallow land, and re-converting it to pasture and hayfields.

The objective in this research is to determine the availability and suitability of growing grass for biomass, with an emphasis on high-yielding perennial grasses such as reed canary grass (Phalaris arundinacea), as in [5]. According to [6], land for perennial grass production in the United States has been projected to come from the land currently in crop production, land currently enrolled in the Conservation Reserve Program, and pastures. A fundamental question regarding the feasibility of producing grass as a biomass feedstock for renewable energy use in Aroostook is whether there is a sufficient area of suitable land [2]. In general, suitable land has drainage, soil type, fertility, and other soil characteristics to support adequate grass yield, and it is not currently used for profitable production of potatoes, broccoli, or other high-value row crops [2].

GIS (geographic information systems) was applied in this research to help perform land availability and suitability analysis. GIS is an effective and reliable mapping technology used to map land cover and land use (LCLU). As pointed out by [7], GIS plays a critical role in handling multisource remote sensing data and the integration of GIS and remote sensing is emerging as an appealing research direction that can be applied to image classification. GIS also allows further spatial analysis of the data derived from remotely sensed imageries. Generally, LCLU datasets are derived from multisource remote sensing data by using image processing software and analyzed by using GIS. In the study area, however, the only available LCLU datasets prior to this study were based on Landsat TM and Landsat ETM (with a spatial resolution of $30 \mathrm{~m}$ ) - for example, the MELCD 2004 land cover map derived from the imagery obtained during the years 1999-2001 and refined using 2004 SPOT 5 panchromatic imagery (with a spatial resolution of $5 \mathrm{~m}$ ) [8] and the land cover map made through Maine Gap Analysis Project on 1991 and 1993 imagery in 1999 [9]. Recent release of very high spatial resolution ( $\leq 1 \mathrm{~m}$ pixel size) satellite multispectral data such as DigitalGlobe Precision Aerial Imagery (RGB; at 30-cm pixel size) and color-infrared imagery 
(CIR; at 60-cm pixel size) [10] makes it possible to carry out high-precision LCLU mapping in rural agricultural and grassy areas such as northern Maine.

In this study, we selected four major townships in the Aroostook River watershed-Presque Isle, Caribou, Fort Fairfield, and Easton - that have a combined area of 71,176.5 hectares (Figure 1). The selected area is the commercially most important agricultural area in Maine [3]. This paper is intended to present our LCLU mapping with the very high spatial resolution multispectral imagery data by applying the established image classification and GIS mapping methods as a case study. The goal is to use the findings from this mapping to assess potential land availability and suitability for grass biomass production or other sustainable use of the underutilized land in the region. Linking knowledge to action, the results provide baseline data for decision makers and stakeholders (planners, developers, town officials, and farmers) to make informed decisions on land-use planning and policy for sustainable development [11-13].

\section{Materials and Mapping Methods}

Land cover (LC) corresponds to a physical description of space and the observed biophysical cover of the earth's surface determined by human observation or remote sensing devices, whereas land use (LU), in terms of the functional dimension, corresponds to the description of areas in terms of their socio-economic purpose [14]. Remote sensing data plays a critical role in LCLU mapping due to its ability to provide a synoptic overview of large areas and a much broader portion of the spectrum than the human eye (e.g., [15-17]). In the past, LCLU mapping was largely based on low- to moderate-spatial resolution remote sensing data (such as Landsat TM and ETM, SPOT, ASTER, and HYPERION) with its coverage mostly at regional to global levels (e.g., [18-20]). As such, the resulting LCLU maps, due to their low spatial resolution and accuracy, could hardly satisfy the precision and accuracy needs of a smaller area such as a township in the Unites States. Recent availability of very high spatial resolution remote sensing data such as the DigitalGlobe Precision Aerial Imagery and multispectral data makes it possible to map LCLU to satisfy high precision and accuracy needs. This study applied established automatic spectral classification to very high spatial resolution multispectral remote sensing data, and ground-truthing, field mapping, and land-owner interviews were intensively used to improve the automatic method and to enhance the accuracy of the final maps.

LCLU for the four Aroostook River Valley townships was mapped and analyzed using ArcGIS. For each township, a GIS database was created by using layers of data including DigitalGlobe's Precision Aerial Imagery RGB data and color infrared imagery (CIR) [10]. Both were captured in June 2011. In addition, high spatial resolution (at 2-m pixel size), LiDAR-derived digital elevation model (DEM) data, such as ground slope and hill shade raster data (released by Maine's Office of GIS in April 2013 [21]), were used, in particular when interpreting old, abandoned farm fields (currently shown as advanced fallow or young forests). The CIR raster was classified based on the CIR reflectance spectrum from different types of vegetation and non-vegetation surface (i.e., land cover), using the unsupervised classification method built with ERDAS Image Analysis Extension for ArcGIS 10. The unsupervised classification is a method of partitioning remote sensing image data in multispectral feature space and extracting land-cover information. The method is particularly useful and effective in areas with high heterogeneity of land cover [22] such as the study area. It allows classes to be determined by spectral distinctions inherent in the data so that users can define the classes later, and it also allows users to easily define many classes. 
The ERDAS Image Analysis Extension uses the Iterative Self-Organizing Data Analysis Technique (ISODATA) clustering algorithm [23] for its unsupervised classification. In the ERDAS Image Analysis unsupervised classification tool, the input parameter Desired Number of Classes (i.e., number of spectral classes) is arbitrary and user-determined. In the study area, based on initial field investigation and examination of the CIR data imagery, the land surface types include at least buildings, roads, parking lots, water bodies (either clear or cloudy with dirt), forest with a number of combinations of different species of trees (and trees in different health and growing conditions), flooded cropland, cropland either with vegetation cover or without any vegetation cover (because the CIR was captured in June when the active cropland used for planting potatoes was still bare), grassland with a number of combinations of grass and shrubs, and wetland. These land surface types show different spectral reflectance in CIR. Therefore three numbers-10, 15, and 20-were used as the Desired Number of Classes during the unsupervised classification test phase, and it was determined that the number 15 was the best (with 20 being unnecessarily high and 10 too few). Each class (in this study, each class is a CIR spectral class) was ground-truthed by means of direct field observation. After the classification, similar classes (for example, all tree classes) were assigned the same color for easy on-screen feature delineation and digitization by using ArcGIS symbolization method.

The land-use types in the four townships were identified and determined based on intensive field investigation, in addition to interpretation of the very high spatial resolution RGB imagery. Ten land-use types were established in this study and are listed below (one exception was that for the township of Fort Fairfield, vineyard was mapped as an independent land-use class from the forest class and the wasteland class was not mapped out). Among all these land-use types, fallow-1, fallow-2, pasture, and hayfield were the focus of this study.

Cropland - farmed for potatoes, small grains, broccoli, and other rotation crops;

Forest - forest of any trees, also including tree farms and orchards;

Pasture - grassland used for animal grazing and often fenced;

Hayfield - grassland harvested for hay;

Fallow-1 - early successional grassland consisting of an array of low vegetative growth, lacking shrub and small-tree growth found in later succession, and not being used as pasture or harvested for hay. It is generally dominated by grasses and herbaceous plants, including some of or all of timothy, ryegrass, smooth bromegrass, reed canary grass, clover, Canada thistle, goldenrod, and burdock (Figure 2a);

Fallow-2 - later successional growth of fallow-1, containing some shrubs (mostly red-osier dogwood and willows) and young trees (such as Populus, Betula, Pinus, and Picea) in addition to grasses and herbs (Figure 2b). Fallow-2 would become entirely forested (Figure 2c);

Wetland - land areas saturated with water, either permanently or seasonally, including marsh, swamp, bog, and fen;

Water bodies - including lakes, ponds, and rivers/streams;

Developed - lands developed either for residential, commercial, and industrial uses with man-made structures or for non-agricultural, industrial operations, such as gravel pits and rock quarries;

Wasteland - open, marginal lands, for example with dumped rocks or waste, steep slopes, dampness, or low fertility. They are mostly adjacent to farm fields; 
Other uses - such as roadways, railways, transmission lines (these were mapped as "developed" for the townships of Fort Fairfield, Easton, and Presque Isle).

For each township, a vector-type polygonal feature class was created and used for LCLU digitization. The classified CIR and the very high resolution RGB images were utilized to provide insight to land cover and land use; ArcMap was used for manual on-screen digitization to map land in all four townships into separate plots at a 1:5000 scale (or even larger in areas where more efforts were needed to determine boundary location); then, a land-use type was assigned to each plot, based on interpretation of land cover on the very high resolution RGB and classified CIR images.
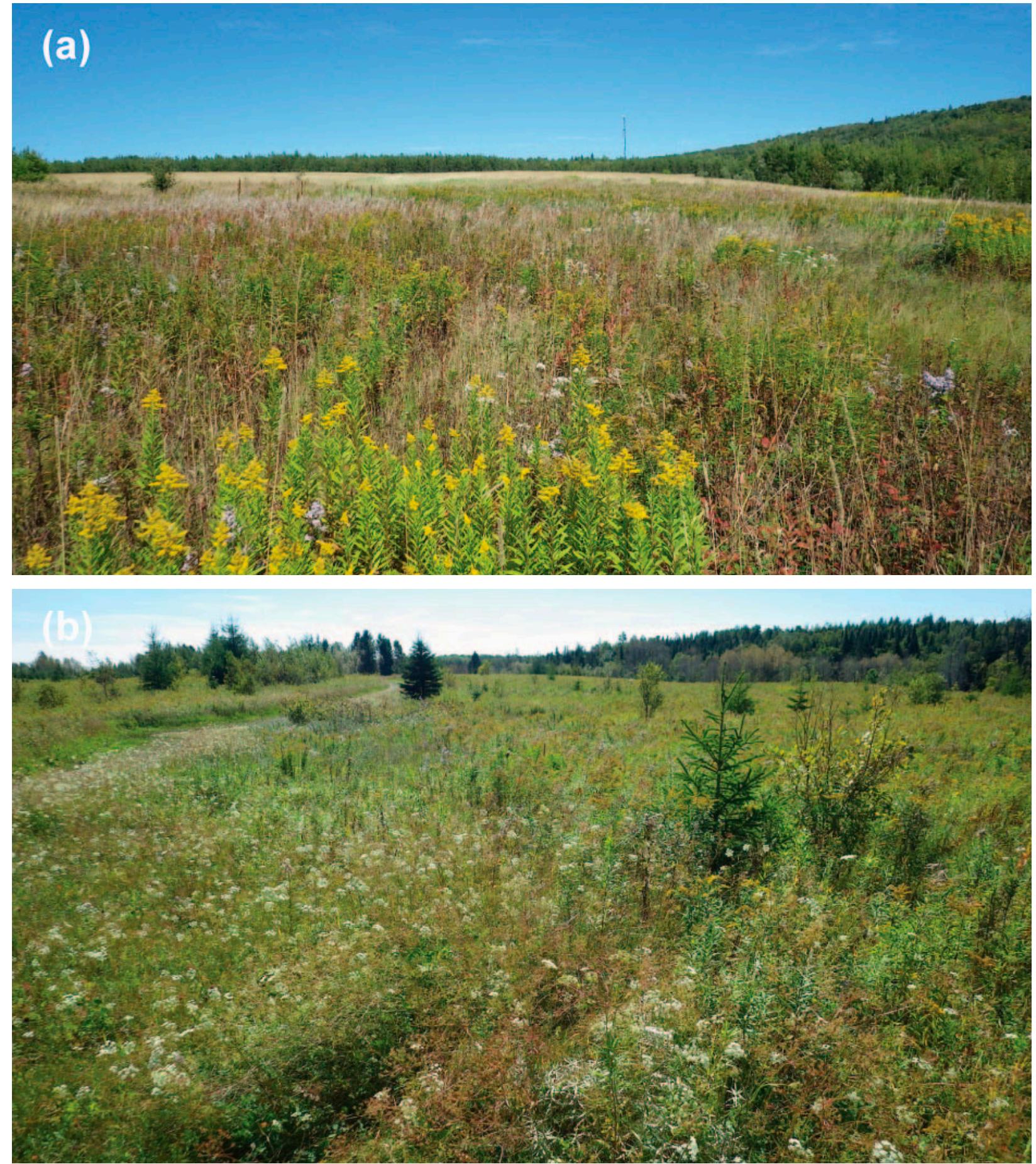

Figure 2. Cont. 


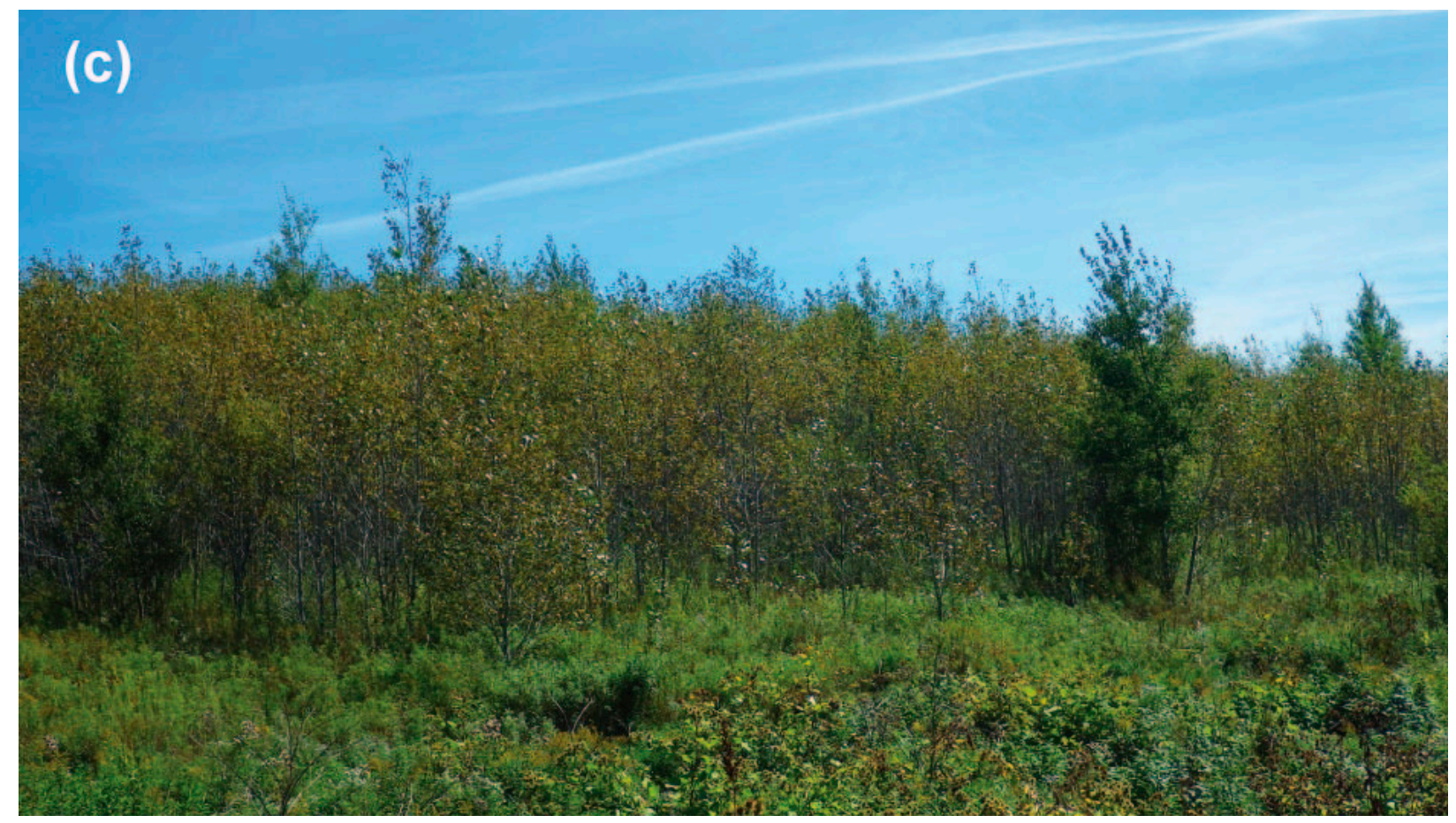

Figure 2. Examples of fallow lands. (a) Fallow-1; (b) fallow-2; (c) forested fallow beyond fallow-2 (dominated by balsam poplar (Populus balsamifera)) for at least 20 years. See the text for detailed explanation.

The high-precision mapping for both Fort Fairfield and Easton townships was conducted in 2012 and 2013 and was based on the DigitalGlobe Precision Aerial Imagery very high resolution RGB and CIR images captured in June 2011. Google Earth's recently released very high resolution images (at 15-cm pixel size; captured in September 2013 [24]) was also used in addition to the DigitalGlobe 2011 images in mapping the Presque Isle and Caribou townships during winter 2013 and summer 2014.

An accuracy assessment [25] was conducted to measure the reliability of the manual on-screen digitization and classification processes. This involved visiting land-use plots, in particular the grassland plots identified as fallow-1, fallow-2, hayfield, and pasture lands by on-screen digitization and interpretation, and interviewing land owners for the plots with uncertainty. For example, every grassland plot of 2 hectares or larger was investigated in the field and ground-truthed. Errors in the initial manual assignment of land-use type were immediately corrected on-site. Field investigations also provided feedback to improve on-screen digitizing accuracy in the laboratory. The land-use map for each township was thoroughly examined in the field before it was called "completed".

The completed land-use GIS databases were analyzed with ArcMap summary and statistic tools to provide statistical information on: total hectarage of each land-use type, total hectarage of fallow-1 and fallow-2 plots equal to or over 10 U.S. acres (equivalent to 4.05 hectares) in size, and the total number of plots for each land-use type.

Good soil drainage is a preferable factor for grassland to be suitable for growing perennial energy grasses such as reed canary grass and switchgrass [26-29]. For example, experimental plots of reed canary grass and switchgrass in three separate trial sites grown in the study area in 2010, 2011, and 2012 demonstrated that good soil drainage produced higher biomass yield [30]. In general, suitable land for growing perennial energy grasses for a high yield shall have good soil drainage, loam or loamy soils, 
a "not hydric" rating, and low slope steepness [31-33] (Table 1). As indicated by the Natural Resources Conservation Service (NRCS) of the United States Department of Agriculture [34], fields with steep or irregular terrain and excessively wet areas shall be avoided because of their negative effect on stand establishment and management and on field and harvest operations. Other factors such as $\mathrm{pH}$ and fertility may also affect quality of energy grass growth and yield [26-30,34]. However, due to lack of such data in the study area, this study could not perform suitability analysis in terms of $\mathrm{pH}$ and fertility.

Table 1. General land suitability factors for optimal perennial energy grass yield.

\begin{tabular}{ccc}
\hline & Suitable & Non-Suitable \\
\hline Soil Drainage [26-29] & Well drained to somewhat poorly drained & Poorly to very poorly drained \\
Soil Hydric Rating [34] & Not hydric soils & Hydric soils \\
Soil Type [35,36] & Loam or loamy, sandy soils & Heavy clay soils \\
Slope [31-33] & Low (for example, equal or less than 15\%) & High (for example, higher than 15\%) \\
\hline
\end{tabular}

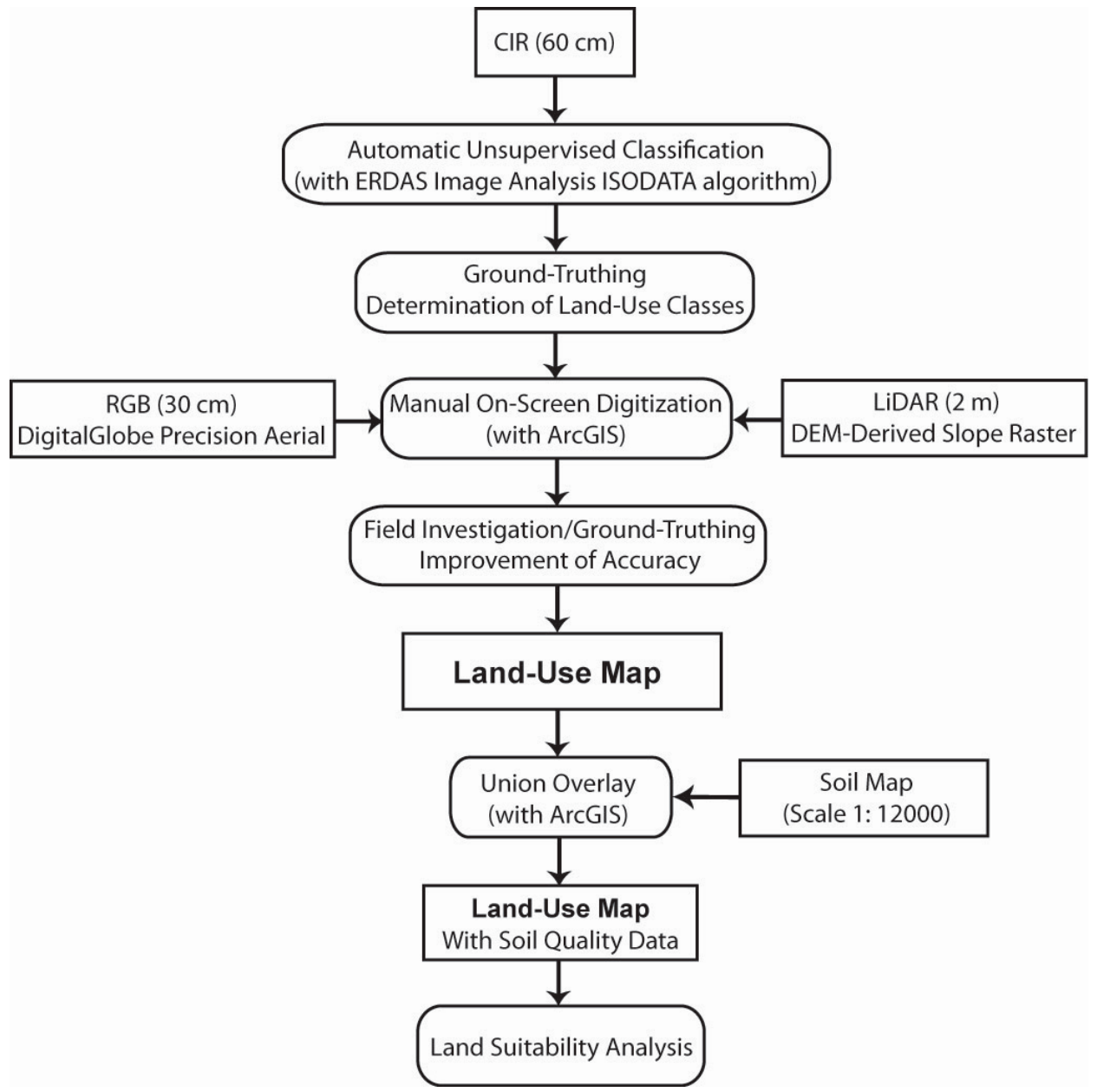

Figure 3. Flowchart showing methodological steps of the GIS mapping in this study.

In the land suitability analysis in this study, the ArcGIS union overlay analysis between the newly generated land-use data layer and soil survey data layer was performed and the union overlay generated a new data layer combining attributes from both layers. The soil survey in the study area was conducted at a 1:12,000 scale - the survey data was initially released in 1964 and digitized in 2006 by the NRCS of the United States Department of Agriculture [37]. The soil layer attribute table contains information 
about soil type, soil drainage class, farmland classification, hydric rating, slope steepness, and soil erodibility rating. With this new data layer a GIS statistical analysis was performed to quantify land suitability for growing grass in terms of soil quality (i.e., soil drainage, soil type, and hydric rating) and agricultural usability.

The methodological steps described above are summarized in a flowchart (Figure 3).
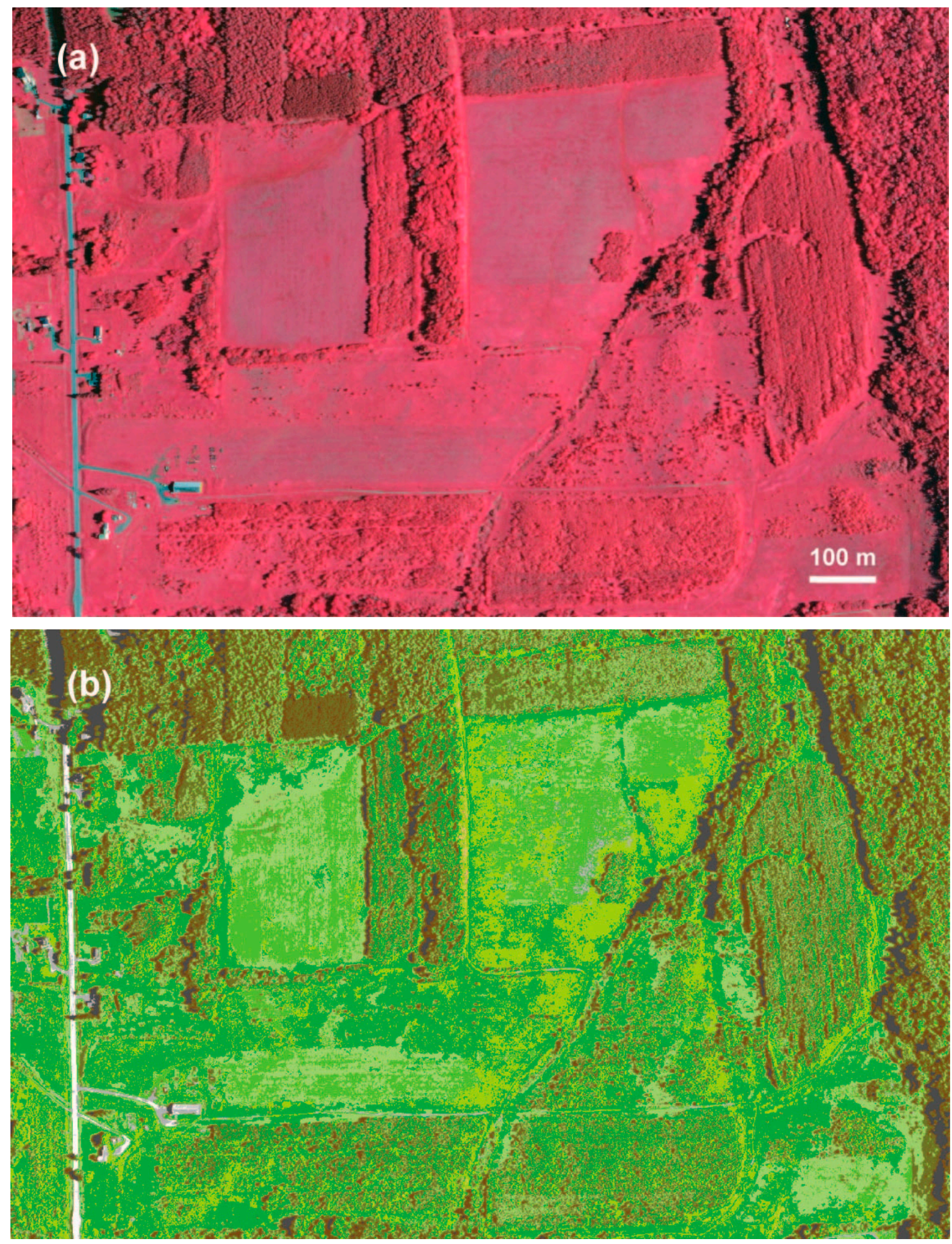

Figure 4. Cont. 

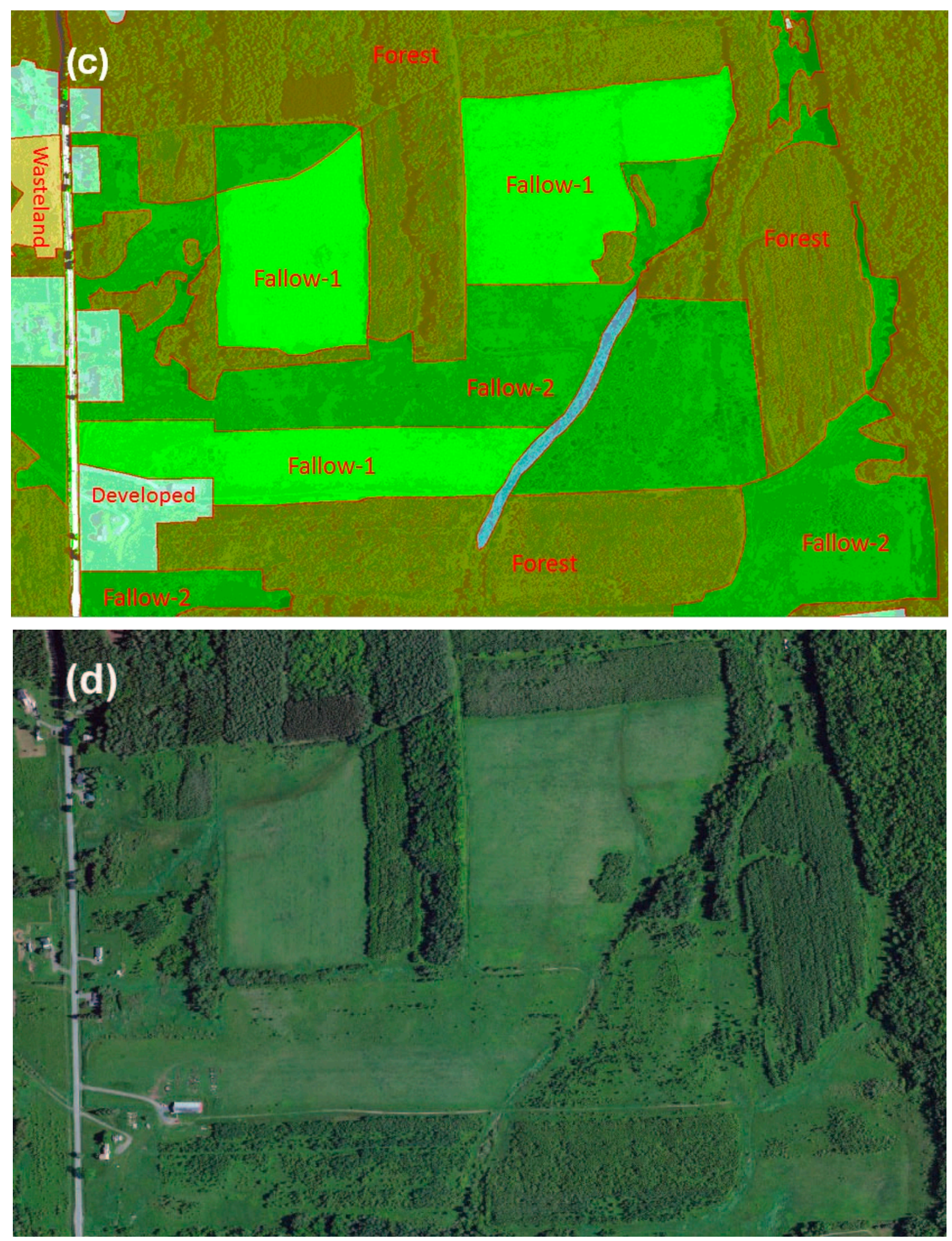

Figure 4. Sample images of the same location and extent showing CIR data classification and interpretation of land use. (a) CIR imagery; (b) classified CIR imagery; (c) land-use map (overlaying on classified CIR); (d) visible light, true-color imagery.

Figure 4 demonstrates how a land-use map was made based on CIR data classification, direct interpretation of very high spatial resolution RGB images, and field investigation. Figure 5 shows how LiDAR-derived DEM slope and hill shade data were useful in interpretation of later successional fallow 
lands and in studying historic changes to cultivated lands, e.g., they showed historic evidence of tilling even in currently forested lands.
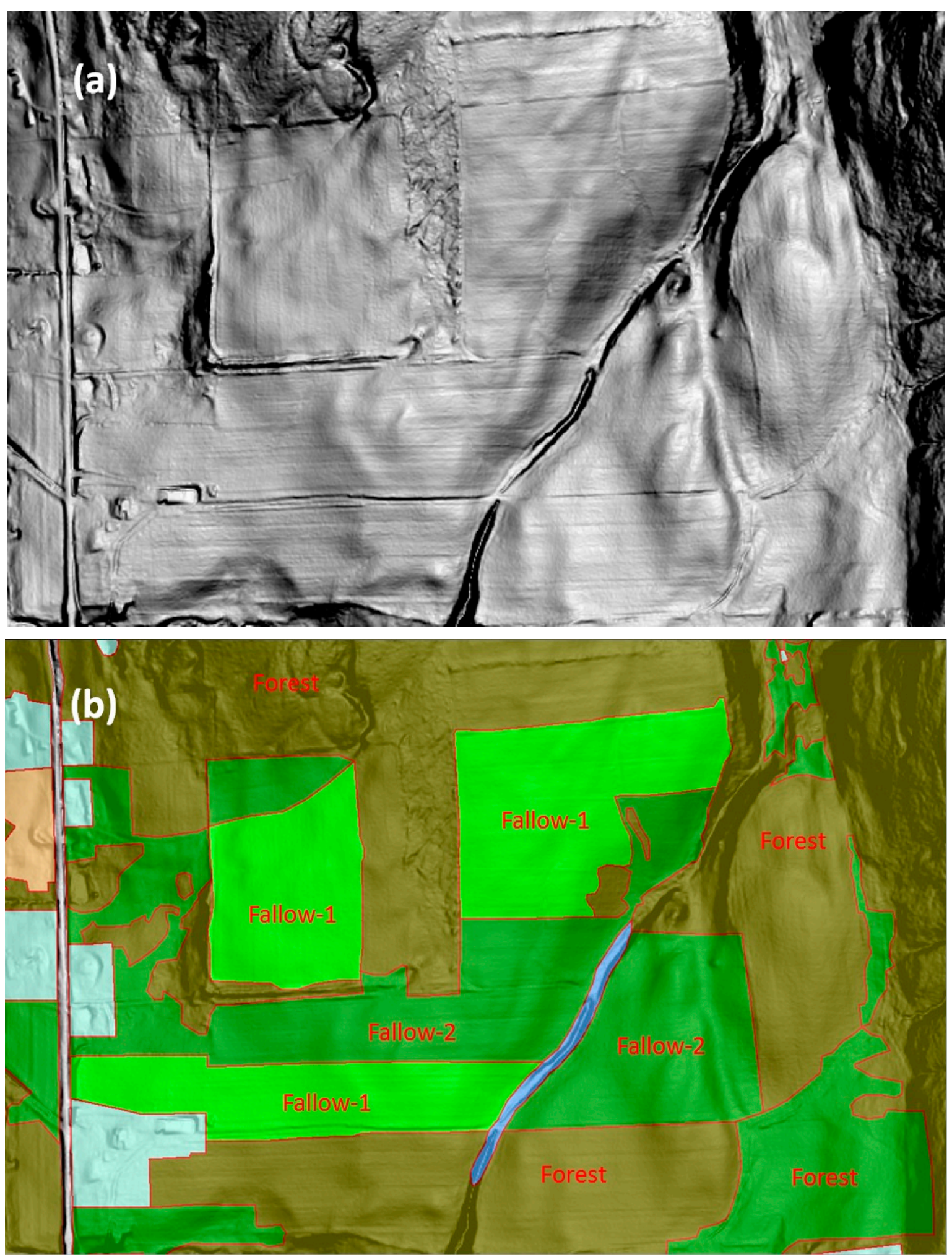

Figure 5. LiDAR-derived ground slope raster layer (a) clearly reveals old cultivated land characterized by smooth surface and fine linear features as a result of long-time tilling, some of which are either fallow-2 or completely forested as indicated in (b) and shown in Figure 2c. The extent of both maps is identical to Figure 4. 


\section{Results and Discussion}

High-precision land-use mapping has resulted in separate land-use GIS databases for each township. Based on the GIS databases, land-use maps were generated with ArcMap. The Appendix includes land-use maps for the four townships. Linking knowledge to action, after the mapping project was completed for each township, the digital land-use GIS data and printed land-use maps were immediately shared with our stakeholders, such as the Northern Maine Development Commission, the Maine Farm Bureau, local town offices, and land management agencies. For example, the land-use map and data were quickly adopted as baseline data for the town of Easton's comprehensive planning project.

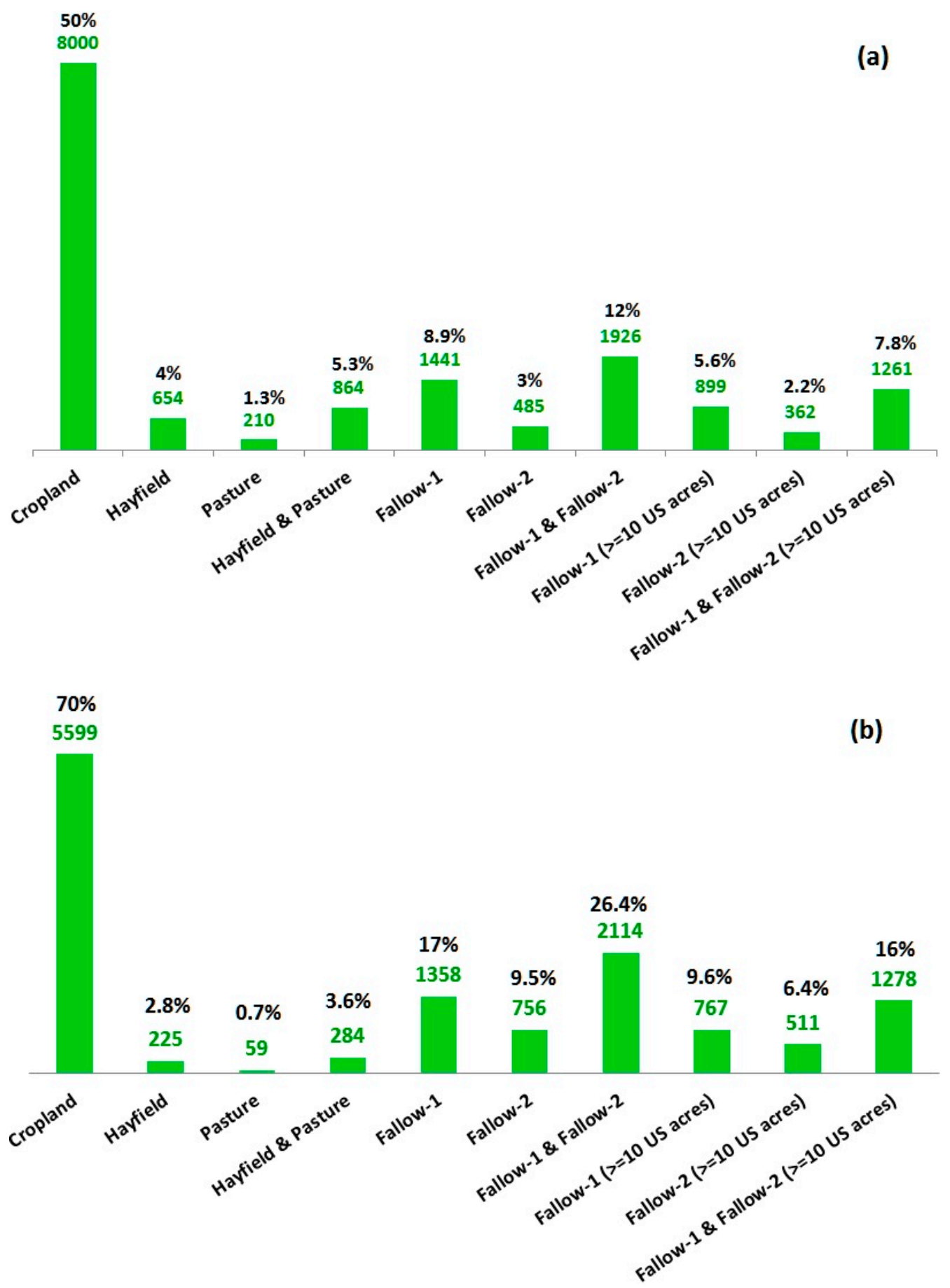

Figure 6. Cont. 


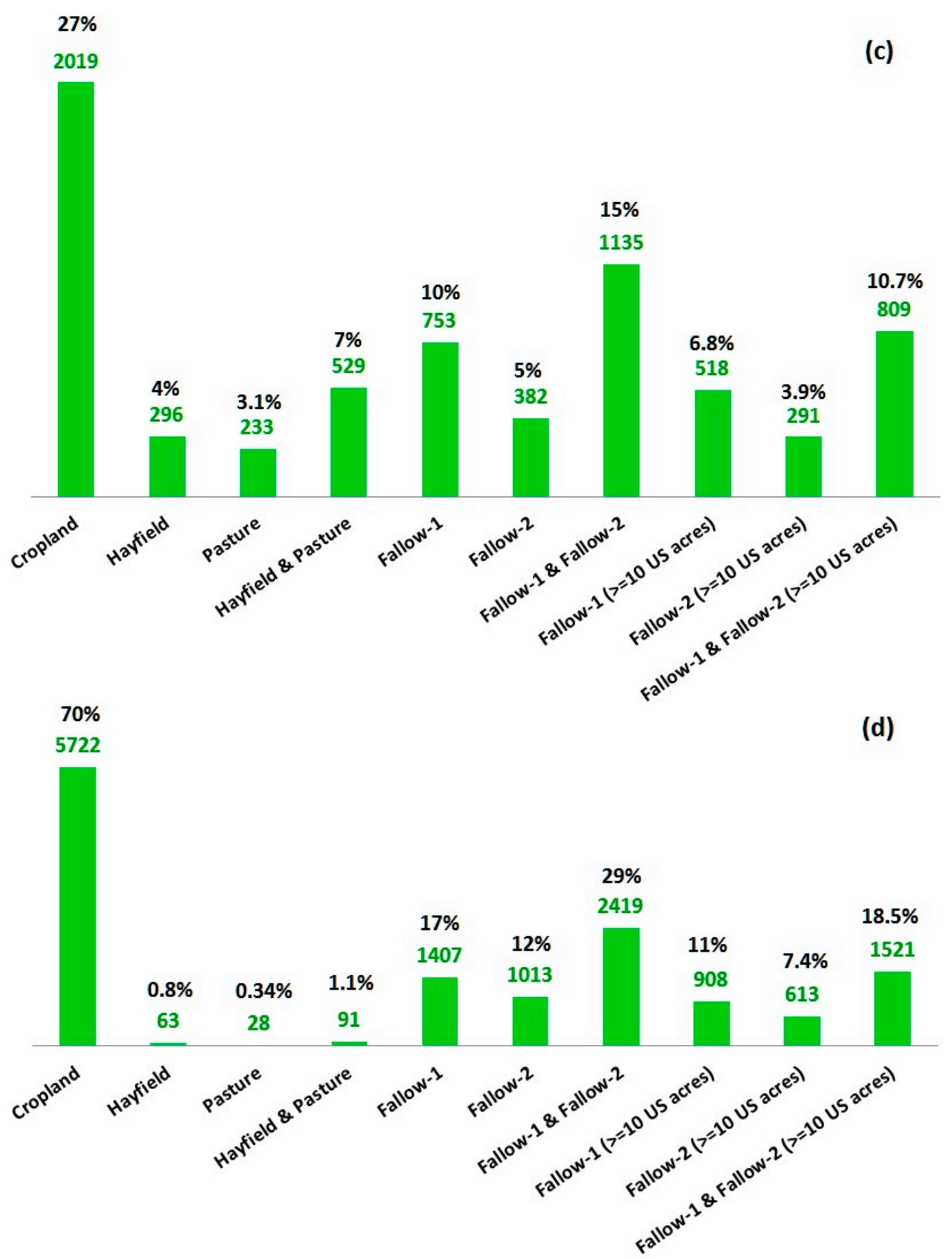

Figure 6. Land area (hectares) and percent coverage of current land uses within the four townships of Fort Fairfield (a), Presque Isle (b), Easton (c), and Caribou (d). Percentages are based on total open land ("open land" refers to all land uses except for forests, water bodies, wetlands, wastelands, and developed lands). The last three categories are for plots that are equal to or greater than 10 U.S. acres (or 4.05 hectares).

Total area and percent coverage by land use types (Figure 6) was summarized for the entire local focal area as well as by township (In the bar graphs, "open lands" include all land uses except for forests, water bodies, wetlands, wastelands, and developed lands). Summarily (Figure 7), for the four townships 
of Presque Isle, Caribou, Fort Fairfield, and Easton, hayfields make up 1238 hectares, pasture 531 hectares, fallow-1 4959 hectares, and fallow-2 2635 hectares. The combined hectarage of fallow-1 and fallow- 2 is 7594 , which accounts for $25 \%$ of the total open lands in the four townships. The total amount of fallow-1 and fallow-2 land plots over ten U.S. acres (equivalent to 4.05 hectares) in size is 4870 hectares, which accounts for $16 \%$ of the open lands.

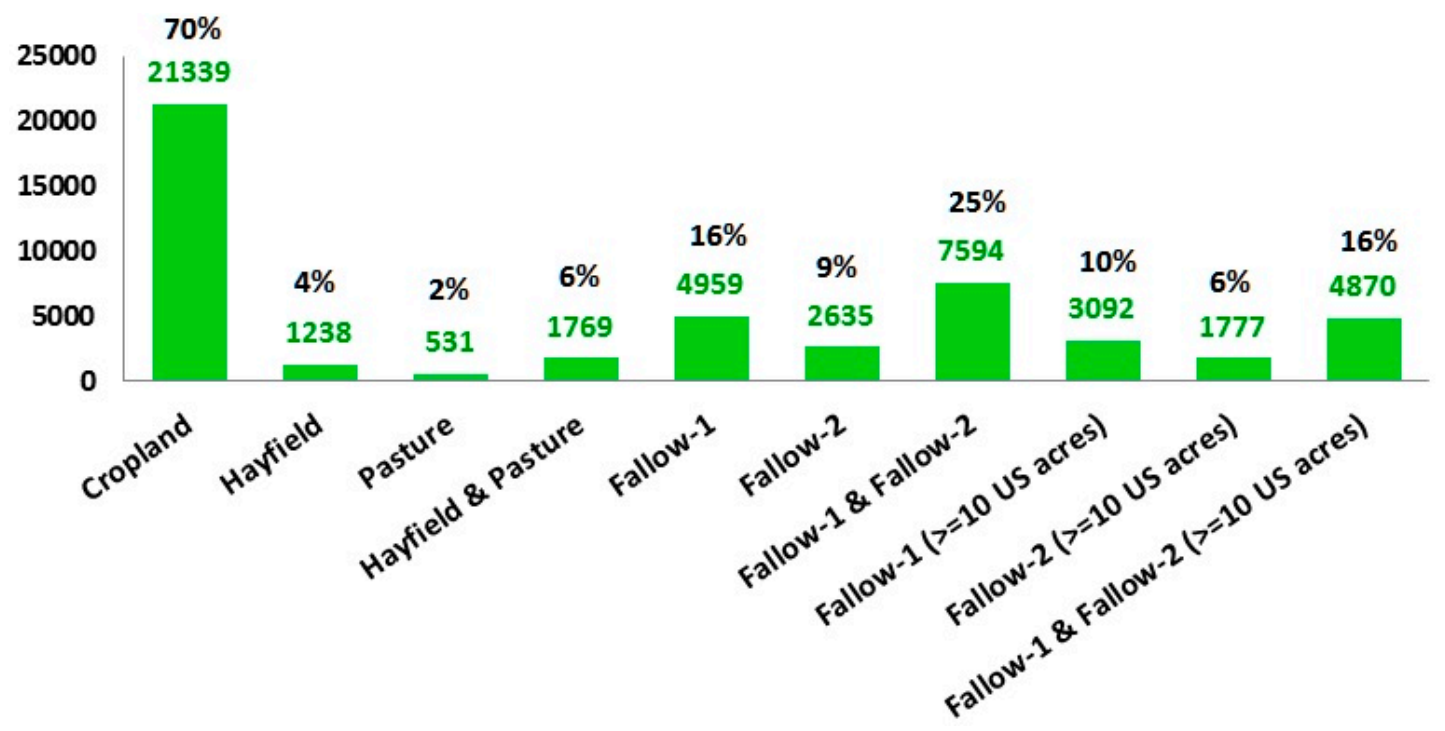

Figure 7. Land area (hectares) and percent coverage within all the four townships combined. Percentages are based on total open land ("open land" refers to all land uses except for forests, water bodies, wetlands, wastelands, and developed lands). The last three categories are for plots that are equal to or greater than 10 U.S. acres (or 4.05 hectares).

Total area and percent coverage by land use types (Figure 6) was summarized for the entire local focal area as well as by township (In the bar graphs, "open lands" include all land uses except for forests, water bodies, wetlands, wastelands, and developed lands). Summarily (Figure 7), for the four townships of Presque Isle, Caribou, Fort Fairfield, and Easton, hayfields make up 1238 hectares, pasture 531 hectares, fallow-1 4959 hectares, and fallow-2 2635 hectares. The combined hectarage of fallow-1 and fallow- 2 is 7594 , which accounts for $25 \%$ of the total open lands in the four townships. The total amount of fallow-1 and fallow-2 land plots over ten U.S. acres (equivalent to 4.05 hectares) in size is 4870 hectares, which accounts for $16 \%$ of the open lands.

Manual on-screen digitization and interpretation accuracy was assessed based on the classified CIR and visible light RGB images during the mapping process for each township. For example, in mapping Caribou township land use, 480 digitized land-use plots were selected for accuracy assessment. Based on field investigation and ground-truthing of the plots, 367 of them were found to be accurate $(76.5 \%$ total accuracy). A closer look at the incorrect land-use types revealed that $52.5 \%$ of the incorrect types were attributed to land cover and land use changes since the satellite imageries had been captured (for example, fallow-1 progressing to fallow-2, fallow land becoming developed, or tilled cropland being abandoned to become fallow). Accuracy assessment of manual on-screen digitization and interpretation for the other three townships yielded total accuracy of 82\% for Fort Fairfield (369 of 450 plots were 
accurate), 79\% for Presque Isle (340 of 430 plots were accurate), and 84\% for Easton (319 of 380 plots were accurate).

It must be pointed out that because the LCLU mapping in this study was largely based on manual on-screen digitization and interpretation of the classified CIR and the 30-cm and 15-cm RGB images, the accuracy assessment was not performed on the automatically-classed, pixel-based CIR land-cover raster but the original manually-assigned, plot-based vector land-use map during the mapping process. It was not an accuracy assessment on the final land-use maps (which were made after accuracy assessment, field examination, land owner interview, and error correction). This is different from traditional accuracy assessment of automatic image classification [38]. In addition, considering the uncertainty for interpretation of classes of the developed, water bodies, wetland, and forest from the very high resolution images was really very low, it was decided that the accuracy assessment would focus on classes of grassland and fields of skeptical cropland that grew green vegetation cover (because the image was captured in early June of mid-latitude Maine when non-tilled cropland began to grow grass or winter rye), similar to young fallow land. About $80 \%$ of the assessed land-use plots for each township were initially mapped as plots of fallow-1, fallow-2, hayfield, pasture, and cropland. Therefore it is not necessary to separately assess the accuracy of grassland class mapping results. For high accuracy in the final land-use maps, as previously indicated, all the plots of grassland and suspected grassland equal or greater than 2 hectares were field-investigated and mapped, and land owners of plots that still exhibited uncertainty were interviewed. The final land-use maps made in this study and the estimated hectarage of the grassland are highly reliable.

The union overlay between the GIS land-use data layer and the soil survey data layer was performed for identification of plots with soil optimal for growing grass; it generated a new data layer combining attributes from both layers. With this new data layer the GIS Summary and Statistical analysis tools were performed to quantify land suitability for growing grass in terms of soil quality (i.e., soil drainage, hydric rating, soil type, agricultural usability, etc.). For example, ArcGIS was used to identify (with its Selection by Attributes tool) plots of grassland that were located in "poorly-drained" (defined as "Depth to water table is less than 1 foot" [37]) or "very-poorly-drained" (defined as "Depth to water table is less than 1 foot or is ponded; soils are wet to the surface most of the time" [37]) soils to calculate their hectarage. The results shown in Table 2 clearly indicate that only a very small percentage (4.9\%) of all grassland plots are located in "poorly-drained" or "very-poorly-drained" soils. Conversely, nearly all grassland plots $\mathbf{( 9 5 . 1 \% )}$ ) are on "well-drained" (defined as "Depth to water table is more than 6 feet; soils have intermediate water holding capacity" [37]), "moderately well-drained" (defined as "Depth to water table is 3-6 feet; soils have a layer of low hydraulic conductivity" [37]), or "somewhat poorly drained" (defined as "Depth to water table is 1-3 feet" [37]) soils. The attribute table of the new data layer also shows that the dominant soil types in the mapped grassland plots are "gravelly loam," "silt loam," "fine sandy loam," or "shaly silt loam," and that most of the grassland plots have $0 \%-15 \%$ slopes.

ArcGIS Selection by Attribute and Statistics tools were also used to assess grassland that is classified by the NRCS as either "farmland of state importance" (defined as "Farmland with statewide importance for the production of food, feed, fiber, forage, and oil seed crops" [37]) or "all areas are prime farmland" (defined as "Farmland with the best combination of physical and chemical characteristics for producing food, feed, forage, fiber, and oilseed crops, and also available for these uses; the soils are of the highest quality and can economically produce sustained high yields of crops" [37]). Both farmland importance 
classes have soils rated as "not hydric" in the study area. As shown in Table 3, most grassland plots in each township (the range is $79 \%-90 \%$ ) falls into these classes. Within this class of grassland, more than half $(53 \%-87 \%)$ is either fallow-1 or fallow-2 that used to be arable, prime farmland with high potential for crop and cover crop productivity.

Table 2. Hectarage of grasslands with "poorly-drained" or "very-poorly-drained" soils.

\begin{tabular}{cccc}
\hline Township & $\begin{array}{c}\text { Total Hectarage of Grassland } \\
\text { (including Hayfield, Pasture, } \\
\text { Fallow-1, and Fallow-2) }\end{array}$ & $\begin{array}{c}\text { Hectarage of Grassland in } \\
\text { "Poorly-Drained" or } \\
\text { "Very-Poorly-Drained" Soils }\end{array}$ & Percentage \\
\hline Fort Fairfield & 2791 & 128 & $4.6 \%$ \\
Caribou & 2511 & 108 & $4.3 \%$ \\
Presque Isle & 2398 & 159 & $6.6 \%$ \\
Easton & 1664 & 68 & $4.1 \%$ \\
\hline Total & 9364 & 463 & Average 4.9\% \\
\hline
\end{tabular}

Table 3. Hectarage of grasslands classified as "farmland of state importance" or "all areas are prime farmland" by NRCS.

\begin{tabular}{cccc}
\hline Township & $\begin{array}{c}\text { Total Hectarage of } \\
\text { Grassland (including } \\
\text { Hayfield, Pasture, } \\
\text { Fallow-1, and Fallow-2) }\end{array}$ & $\begin{array}{c}\text { Hectarage/Percentage of } \\
\text { Grassland Classified as } \\
\text { "Farmland of State } \\
\text { Importance" or "All Areas are } \\
\text { Prime Farmland" by NRCS }\end{array}$ & $\begin{array}{c}\text { Hectarage/Percentage of } \\
\text { Fallow (1+2) Classified as } \\
\text { "Farmland of State } \\
\text { Importance" or "all Areas are } \\
\text { Prime Farmland" by NRCS }\end{array}$ \\
\hline $\begin{array}{c}\text { Fort } \\
\text { Fairfield }\end{array}$ & 2791 & $2309(83 \%)$ & $1540(55 \%)$ \\
Caribou & 2511 & $2260(90 \%)$ & $2177(87 \%)$ \\
$\begin{array}{c}\text { Presque Isle } \\
\text { Easton }\end{array}$ & 2398 & $2067(86 \%)$ & $1920(76 \%)$ \\
\hline Total & 1664 & $1317(79 \%)$ & $877(53 \%)$ \\
\hline
\end{tabular}

\section{Conclusions}

The LCLU mapping results demonstrate that the four major townships of the Aroostook River Valley have fallow-1 totaling 4,959 hectares, fallow- 2 totaling 2635 hectares, hayfield totaling 1238 hectares, and pasture totaling 531 hectares. The combined area of fallow-1 and fallow-2, 7594 hectares, accounts for $25 \%$ of the total open lands in the four townships. Only a very small percentage $(4.9 \%)$ of grasslands have "poorly drained" or "very poorly drained" soils; $85 \%$ of grasslands are designated "farmland of state importance" or "prime farmland" that have a "not hydric" rating; the dominant soil types in the grasslands are "gravelly loam," "silt loam," "fine sandy loam," or "shaly silt loam"; and most of the grassland plots have $0 \%-15 \%$ slopes. Based on the results of this study, land of several types is suitable for producing perennial grass as a biofuel feedstock in the Aroostook River Valley region. Existing hay fields plus a substantial portion of current pasture and "fallow-1" land (in plots equal to or larger than ten U.S. acres or 4.05 hectares) would make up the core land base for grass biomass. A farm-level economic analysis performed by the University of Maine at Presque Isle's EPSCoR (Experimental Program to Stimulate Competitive Research) team suggests that U.S. 1000 acres (equal to 405 hectares) or more of grassland 
are needed industrial scale grass bioenergy production at optimum efficiency [30]. Based on that assessment, it was concluded that all four townships in our study area have an ample land base suitable for grass biomass. The high-precision land-use map and estimate of grassland hectarage presented in this study provide important baseline data for regional economic and land planning and decision making.

While the objective of this study was to assess availability and suitability of land for growing grass biomass, the larger value is the quantification and mapping of a substantial land resource of high agricultural value. This knowledge may be used by municipalities, landowners, and agribusinesses to determine the best uses for this underutilized resource. The fallow lands mapped in this study can also be considered for uses other than production of grass biomass. For example, they could be used for cattle or sheep farming, for producing hay, or for food crop production.

This high-precision LCLU GIS mapping project in northern Maine's Aroostook River Valley is the first-ever conducted in the state of Maine. While using multispectral satellite imagery for LCLU interpretation and mapping is not a new method, high-precision (at a 1:5000 scale) LCLU mapping with recently available high-resolution multispectral remote sensing data, integrated with intensive ground-truthing and field investigation provides an effective tool for high-precision land-use mapping at a township level in rural areas of the USA such as northern Maine. This integrated LCLU mapping method is applicable to areas where high-resolution multispectral satellite and LiDAR data are available and large-scale field investigation and ground-truthing can be performed.

\section{Acknowledgments}

This research was supported by National Science Foundation award EPS-0904155 to Maine EPSCoR (Experimental Program to Stimulate Competitive Research) at the University of Maine. The mapping was performed and assisted by the University of Maine at Presque Isle students Scott Belair, Michael Mink, Justine Cyr, Chelsey Ellis, Morgan Svitila, and Zipeng Liu, as well as Presque Isle High School students Sijia Angela Wang, Zachary Rice, and Sedona Lucas, between spring 2012 and summer 2014. We thank Andrew Plant, David Hart, Michael Eckardt, John Peckenham, Linda Silka, Vinton Valentine, and Firooza Pavri for their constructive suggestions and advices throughout the project. We are grateful to officials of the Northern Maine Development Commission (NMDC) and local cities and towns, in particular Robert Dorsey, Alain Ouellette, and Michael Eisensmith of NMDC, Tony Levesque of Fort Fairfield, Jim Gardner of Easton, Ken Arndt of Presque Isle, and Austin Bleess of Caribou for their cooperation and support. We appreciate the constructive comments and suggestions of the three anonymous reviewers who helped greatly improve the manuscript.

\section{Author Contributions}

Chunzeng Wang performed research design, data acquisition, GIS analysis and interpretation, and ground-truthing, and also prepared the manuscript; Jason Johnston participated in research design, data interpretation, discussions on results, and manuscript revision; David Vail contributed to research design, discussions on results, and manuscript revision; Jared Dickinson participated in GIS mapping, data interpretation, field investigation, and land owner interview; David Putnam contributed to research design, discussions and manuscript revision, and assisted in vegetation identification. 


\section{Appendix}

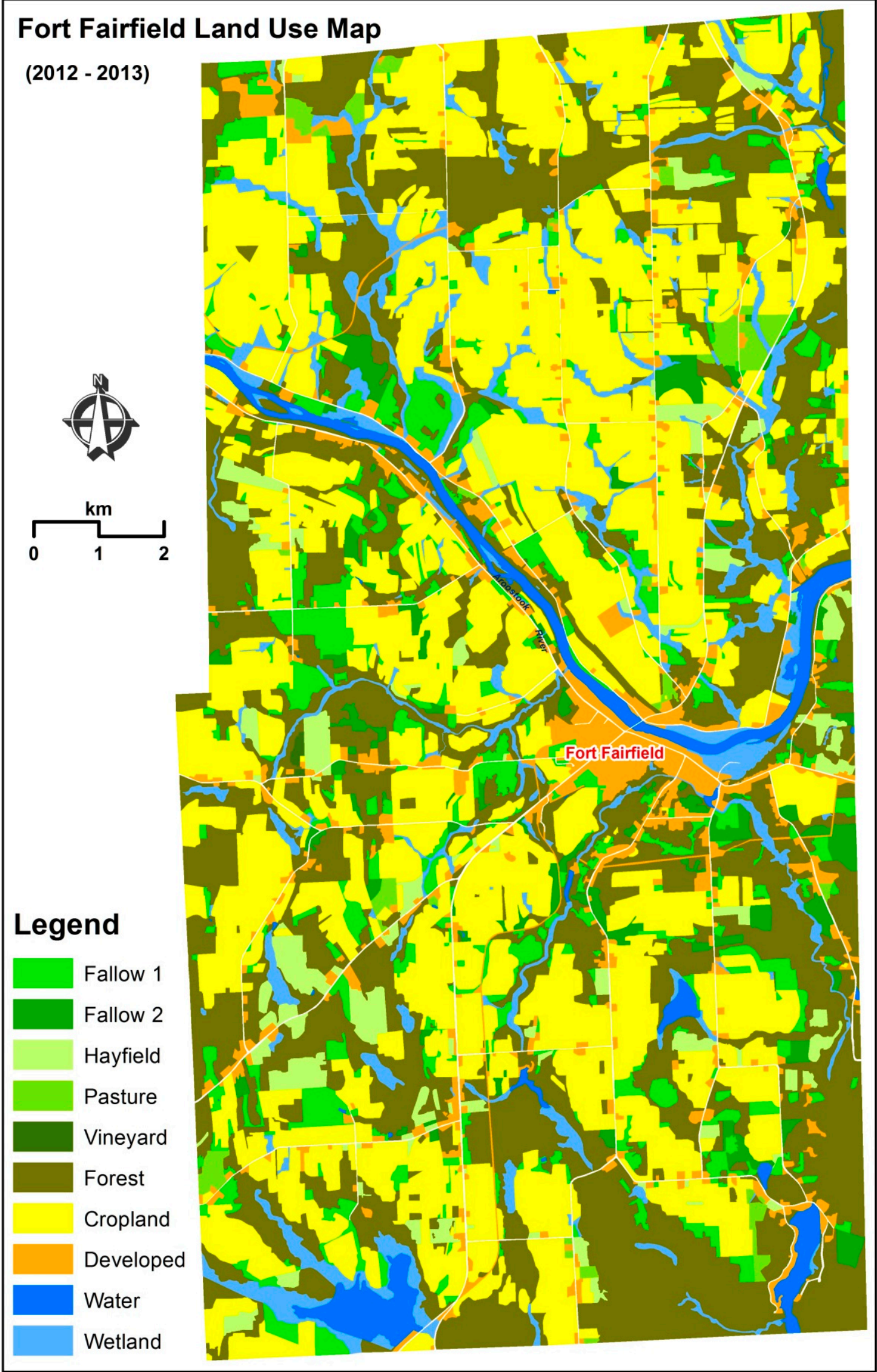

Figure A1. Cont. 


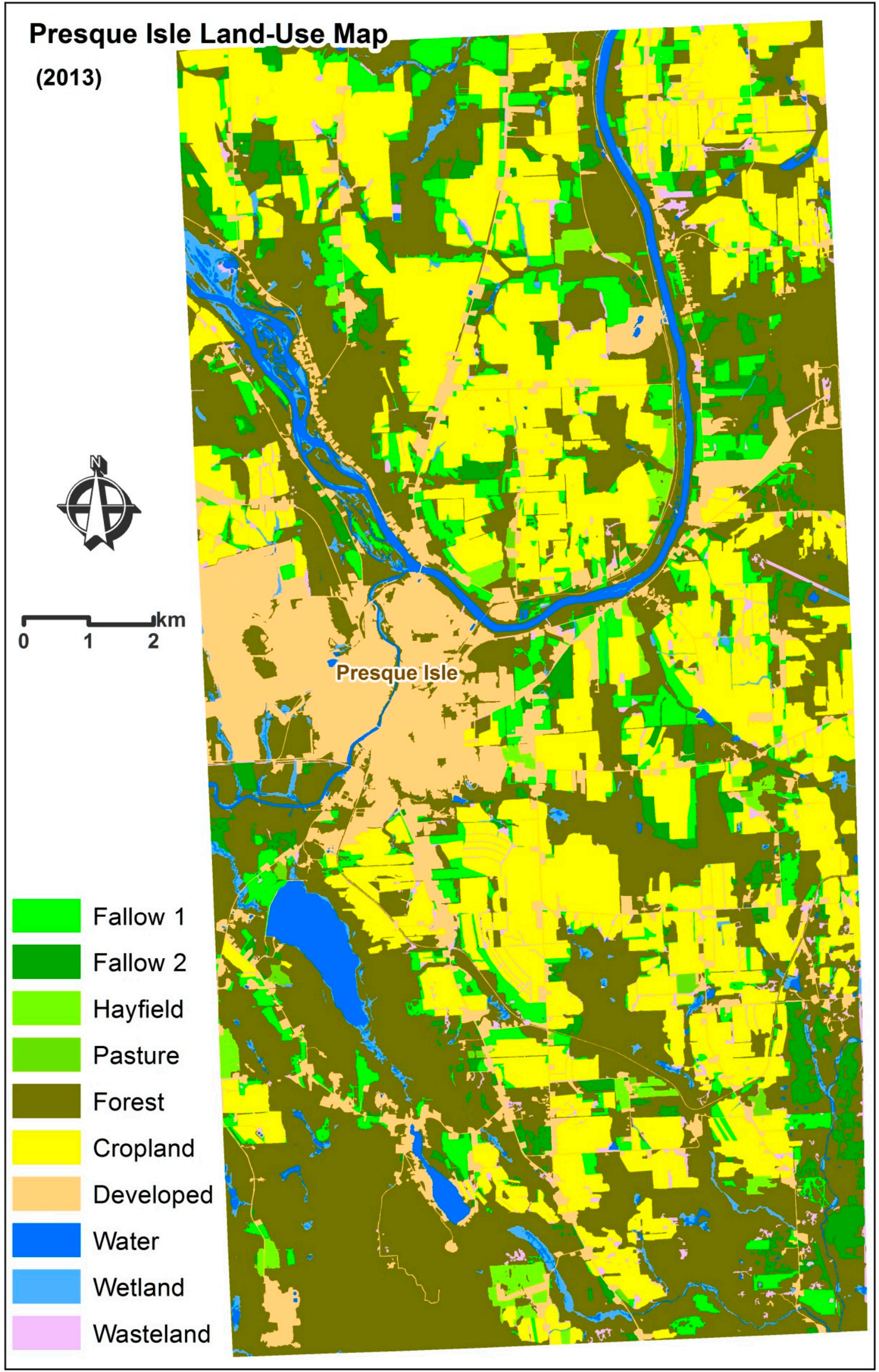

Figure A1. Cont. 


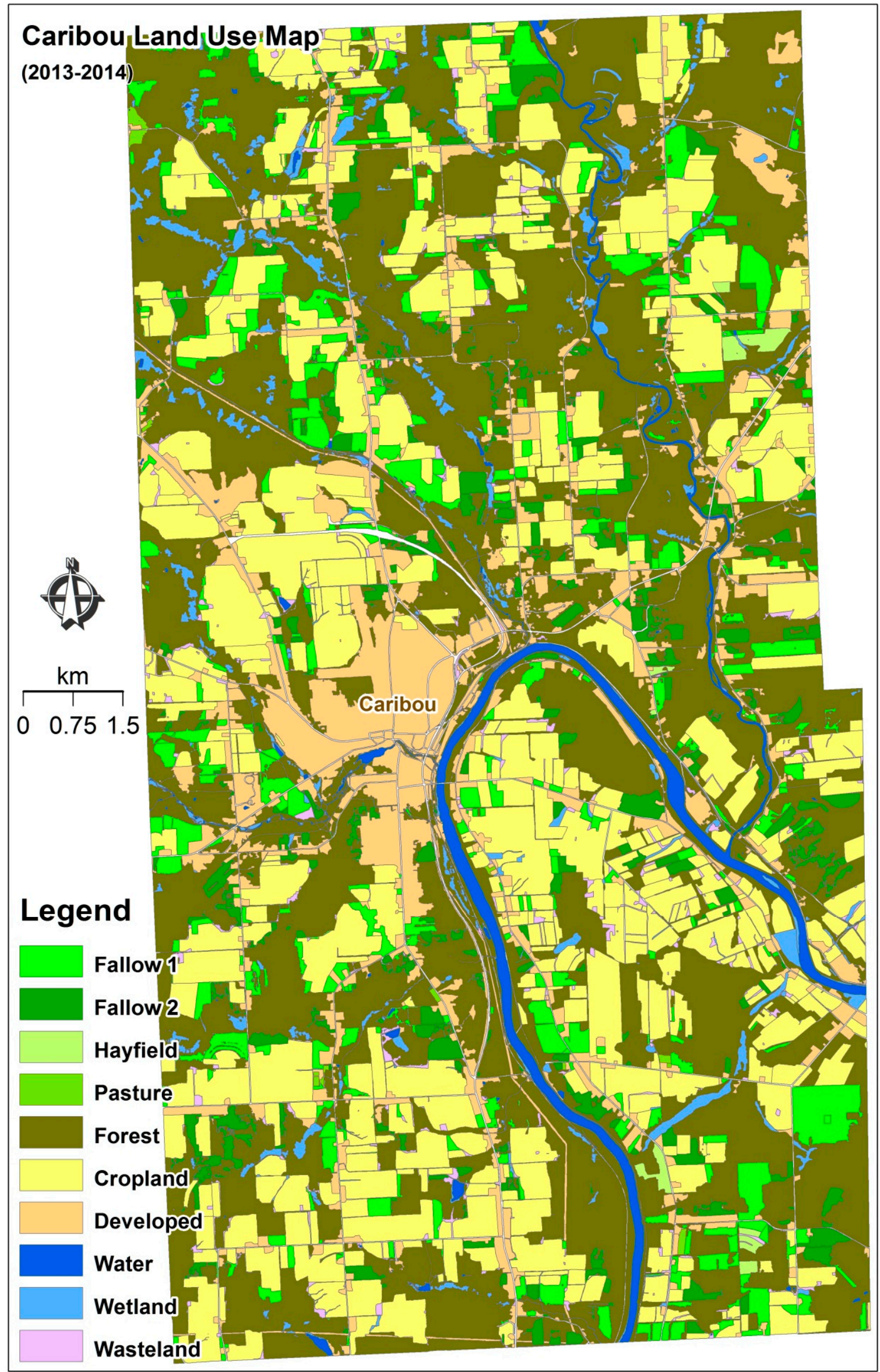

Figure A1. Cont. 


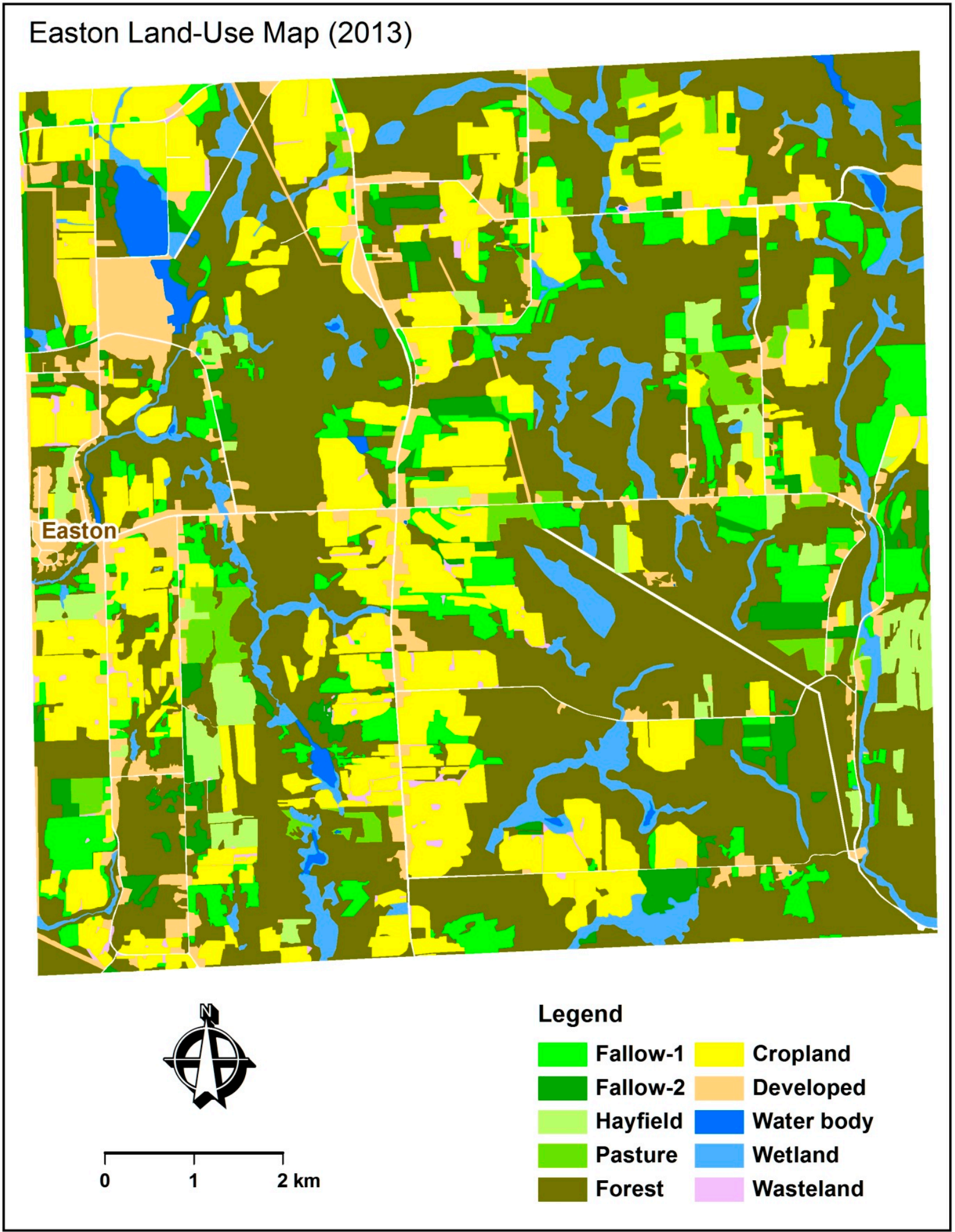

Figure A1. Land-use maps of Fort Fairfield, Presque Isle, Caribou, and Easton.

\section{Conflicts of Interest}

The authors declare no conflict of interest. 


\section{References}

1. Wilson, C.M. Aroostook: Our Last Frontier: Maine's Picturesque Potato Empire; Stephen Daye Press: Brattleboro, VT, USA, 1937; p. 240.

2. Johnston, J.; Cardenas, S. Place-based approaches to alternative energy: The potential for forest and grass biomass for Aroostook County. Maine Policy Rev. 2012, 21, 66-75.

3. National Agricultural Statistics Service. Maine: State and County Data-Volume 1, Geographic Area Series, Part 19, AC-12-A-19; United States Department of Agriculture 2012 Census of Agriculture: Washington, DC, USA, 2014; p. 445.

4. Demirbas, M.F.; Balat, M.; Balat, H. Potential contribution of biomass to the sustainable energy development. Energy Convers. Manag. 2009, 50, 1746-1760.

5. Tahir, M.H.N.; Casler, M.D.; Moore, K.J.; Brummer, E.C. Biomass yield and quality of reed canarygrass under five harvest management systems for bioenergy production. Bioenergy Res. 2011, 4, 111-119.

6. Walsh, M.; de la Torre Ugarte, D.; Shapouri, H.; Slinsky, S. Bioenergy crop production in the United States: Potential quantities, land use changes, and economic impacts on the agricultural sector. Environ. Resour. Econ. 2003, 24, 313-333.

7. Lu, D.; Weng, Q. A survey of image classification method and techniques for improving classification performance. Int. J. Remote Sens. 2007, 28, 823-870.

8. Maine Office of GIS. MELCD 2004. Available online: http://www.maine.gov/megis/catalog/ metadata/melcd.html (accessed on 9 February 2015).

9. Hepinstall, J.A.; Sader, S.A.; Krohn, W.B.; Boone, R.B.; Bartlett, R.I. Development and Testing of A Vegetation and Land Cover Map of Maine; Technical Bulletin 173; Maine Agriculture and Forest Experiment Station, University of Maine: Orono, ME, USA, 1999; p. 104.

10. DigitalGlobe. Data Sheet-Precision Aerial. Available online: https://www.digitalglobe.com/ sites/default/files/AerialProgram-DS-AP-PROD.pdf (accessed on 8 February 2015).

11. Cash, D.W.; Borck, J.C.; Patt, A.G. Countering the loading-dock approach to linking science and decision making: Comparative analysis of El Niño/Southern Oscillation (ENSO) forecasting systems. Sci. Technol. Hum. Values 2006, 31, 465-494.

12. Van Kerkhoff, L.; Lebel, L. Linking knowledge and action for sustainable development. Annu. Rev. Environ. Resour. 2006, 31, 445-477.

13. Hall, D.M.; Silka, L.; Lindenfeld, L. Advancing science and improving quality of place: Linking knowledge with action in Maine's Sustainability Solutions Initiative. Maine Policy Rev. 2012, $21,22-29$.

14. Di Gregorio, A.; Jansen, L.J.M. A New Concept for A Land Cover Classification System; Earth Observation and Evolution Classification: Alexandria, Egypt, 1997; p. 10.

15. Anderson, J.R.; Hardy, E.E.; Roach, J.T.; Witmer, R.E. A Land Use and Land Cover Classification System for Use with Remote Sensor Data; United States Government Printing Office: Washington, DC, USA, 1976.

16. Campbell, J.B. Introduction to Remote Sensing; The Guilford Press: New York, NY, USA, 1987; p. 281. 
17. Giri, C.P. Remote Sensing of Land Use and Land Cover: Principles and Applications; CRC Press: Boca Raton, FL, USA, 2012; p. 477.

18. Loveland, T.; Merchant, J.; Ohlen, D.; Brown, J. Development of a land-cover characteristics database for the coterminous United States. Photogram. Eng. Remote Sens. 1991, 57, 1453-1463.

19. Townshend, J.R.G.; Justice, C.; Li, W.; Guerney, C.; McManus, J. Global land cover classification by remote sensing: Present capabilities and future possibilities. Remote Sens. Environ. 1991, 35, 243-255.

20. Vogelmann, J.E.; Sohl, T.L.; Campbell, P.V.; Shaw, D.M. Regional land cover characterization using Landsat Thematic Mapper data and ancillary data sources. Environ. Monitor. Assess. 1998, $51,415-428$.

21. Maine Office of GIS. Elevation and Derived Products. Available online: http://www.maine.gov/ megis/catalog/ (accessed on 8 February 2015).

22. Vinas, O.; Baulies, X. 1:250,000 land-use map of Catalonia $\left(32,000 \mathrm{~km}^{2}\right)$ using multitemporal Landsat-TM data. Int. J. Remote Sens. 1995, 16, 129-146.

23. Ball, G.; Hall, D. ISODATA, A Novel Method of Data Analysis and Pattern Classification; Stanford Research Institute: Menlo Park, CA, USA, 1965; p. 61.

24. Google Earth Pro 7.1.2.2041. Image Date: 9/28/2013. Location: 46 $35^{\prime} 42^{\prime \prime}-46^{\circ} 57^{\prime} 19^{\prime \prime}$, 67 47'17"-68 $03^{\prime} 56^{\prime \prime}$. Available online: http://www.google.com/earth/index.html (accessed on 8 February 2015).

25. Zhang, X.; Wu, B.; Ling, F.; Zeng, Y.; Yan, N.; Yuan, C. Identification of priority areas for controlling soil erosion. Catena 2010, 83, 76-86.

26. Cherney, J.H. Grass for Bioheat on Farms. Available online: http://www.extension.umn.edu/ agriculture/forages/utilization/docs/cornell-grass-for-bioheat-on-farms.pdf (accessed on 8 February 2015).

27. Cherney, J.H. Production of Grass Biomass in the Northeast. Available online: http://pss.uvm. edu/vtcrops/articles/EnergyCrops/ProductionofGrassBiomassintheNortheastVT_JerryCherney.pdf (accessed on 7 February 2015).

28. Zimmerman, G. Potential of Reed Canary Grass as A Biofuel in Michigan's Eastern Upper Peninsula. Available online: http://www.michigan.gov/documents/dleg/ReedCanaryGrassReport_2 43249_7.pdf (accessed on 8 February 2015).

29. Girouard, P.; Mehdi, B.; Samson, R. Commercial Production of Switchgrass in Eastern Ontario: A Management Guide. Available online: http://www.reap-canada.com/online_library/Reports\%20 and\%20Newsletters/Bioenergy/19\%20Commercial\%20Production.pdf (accessed on 8 January 2015).

30. Johnston, J.; Wang, C.; Plant, A.; Vail, D. Feasibility of Perennial Grass as A Biomass Feedstock in Aroostook County, Maine; Maine EPSCoR Sub-Project Report; University of Maine at Presque Isle: Presque Isle, ME, USA, 2015.

31. Seeruttun, S.; Crossley, C.P. Use of digital terrain modelling for farm planning for mechanical harvest of sugar cane in Mauritius. Comput. Electron. Agric. 1997, 18, $29-42$.

32. Haughton, A.J.; Bond, A.J.; Lovett, A.A.; Dockerty, T.; Sunnenberg, G.; Clark, S.J.; Bohan, D.A.; Sage, R.B.; Mallott, M.D.; Mallott, V.E.; et al. A novel, integrated approach to assessing social, economic and environmental implications of changing rural land-use: A case study of perennial biomass crops. J. Appl. Ecol. 2009, 46, 315-322. 
33. Lovett, A.A.; Sunnenberg, G.M.; Richter, G.M.; Dailey, A.G.; Riche, A.B.; Karp, A. Land use implications of increased biomass production identified by GIS-based suitability and yield mapping for Miscanthus in England. Bioenergy Res. 2009, 2, 17-28.

34. National Resources Conservation Service (NRCS). Planting and Managing Switchgrass as $A$ Biomass Energy Crop; Plant Materials Program Technical Note No. 3; United States Department of Agriculture: Washington, DC, USA, 2009; p. 20.

35. Samson, R. Switchgrass Production in Ontario: A Management Guide; Resource Efficient Agricultural Production (REAP) — Canada: Ste-Anne-de-Bellevue, QC, Canada, 2007; p. 4.

36. Lewandowski, I.; Scurlock, J.M.O.; Lindvall, E.; Christou, M. The development of current status of perennial rhizomatous grasses as energy crops in the US and Europe. Biomass Bioenergy 2003, 23, 335-361.

37. Soil Survey Division Staff. Soil Survey Manual; Soil Conservation Service, U.S. Department of Agriculture Handbook: 18; U.S. Department of Agriculture: Washington, DC, USA, 1993.

38. Foody, G.M. Status of land cover classification accuracy assessment. Remote Sens. Environ. 2002, 80, 185-201.

(C) 2015 by the authors; licensee MDPI, Basel, Switzerland. This article is an open access article distributed under the terms and conditions of the Creative Commons Attribution license (http://creativecommons.org/licenses/by/4.0/). 